\title{
Efektifitas Terapi Mendongeng terhadap Kecemasan Anak Usia Toddler dan Prasekolah Saat Tindakan Keperawatan
}

\author{
Nidaa' A'diilah' ${ }^{1}$, Irman Somantri² \\ ${ }^{1}$ Staff Paramedis Waskita Karya, ${ }^{2}$ Fakultas Keperawatan, Universitas Padjadjaran \\ Email: nidaaadiilah@gmail.com
}

\begin{abstract}
Abstrak
Penelitian ini dilatarbelakangi bahwa hospitalisasi menjadi saat yang memberikan perasaan tidak nyaman bagi anak yang dapat mengakibatkan kecemasan. Hasil studi pendahuluan pada Ruang Anak RS X ditemukan 6 pasien kategori toddler-prasekolah menunjukkan reaksi cemas ketika akan dilakukan tindakan keperawatan, sedangkan 4 pasien sebaliknya. Peran perawat dalam hal ini adalah mendukung perilaku koping anak, menstimulasi perkembangannya, dan mengurangi ketidaknyamanan, salah satu caranya dengan terapi mendongeng. Tujuan penelitian untuk mengetahui pengaruh terapi mendongeng terhadap tingkat kecemasan anak usia toddler dan prasekolah selama tindakan keperawatan. Penelitian ini merupakan penelitian kuantitatif dengan desain eksperimen semu ini menggunakan pendekatan posttest design with a comparison group. Variabel yang digunakan adalah terapi mendongeng dan tingkat kecemasan. Sampel penelitian menggunakan teknik quota purposive sampling, yaitu 15 sampel untuk tiap kelompok. Hasil penelitian menunjukkan mean skor kecemasan toddler 4.40, sedangkan prasekolah 1.80, artinya skor kecemasan prasekolah lebih rendah dibandingkan toddler setelah terapi mendongeng. Simpulan penelitian menunjukkan terdapat perbedaan skor kecemasan pada usia toddler dan prasekolah setelah pemberian terapi mendongeng. Namun, terapi lebih efektif diberikan kepada prasekolah.
\end{abstract}

Kata kunci: Anak, kecemasan, terapi mendongeng.

\section{Effectiveness of Story Telling Therapy towards the Anxiety of Toddler and Pre-school Children during Nursing Intervention}

\begin{abstract}
The background of this study was that children experience anxiety during hospitalization. The initial study in Children Ward Hospital X showed that 6 toddler and pre-school children were experiencing anxiety during nursing intervention, while 4 patients did not show this. Nurses' roles are to support the coping mechanisms of the children, stimulate their development, and reduce their uncomfortableness through story-telling therapy as one of strategies. This study aimed to identify the effectiveness of story-telling therapy to reduce the anxiety of toddler and pre-school children. This study used quasi experimental using posttest design with a comparison group. The variables are storytelling therapy and the anxiety level. Samples were recruited using a quota purposive sampling, which consists of 15 children for every group. The results showed that the mean score of toddler's anxiety was 4.40, while the pre-school children score was 1.80 . This means that the anxiety of pre-school school children were lower than toddler after story-telling therapy. In conclusion, this study showed that there were differences of anxiety scores after story-telling therapy among toddler and pre-school children; however, this therapy is more effective for pre-school children.
\end{abstract}

Keywords: Anxiety, children, story-telling therapy. 
Nidaa' A'diilah : Efektifitas Terapi Mendongeng terhadap Kecemasan Anak Usia Toddler dan Prasekolah

\section{Pendahuluan}

Hospitalisasi, baik itu hospitalisasi jangka pendek, pembedahan, ataupun hospitalisasi jangka panjang dari suatu penyakit yang kronik sering kali menjadi krisis pertama yang harus dihadapi anak, terutama selama tahun-tahun awal. Hal ini sering menimbulkan stres karena anak akan mengalami ketakutan terhadap orang asing yang tidak dikenalnya dan pekerja rumah sakit, perpisahan dengan orang terdekat, kehilangan kendali, ketakutan tentang tubuh byang disakiti, dan nyeri (Potter, 2013). Reaksi-reaksi tersebut dipengaruhi oleh usia perkembangan; pengalaman sebelumnya dengan penyakit, perpisahan, atau hospitalisasi; keterampilan koping yang dimiliki; keparahan diagnosis; dan sistem pendukung yang ada (Hockenberry \& Wilson, 2013).

Cemas akibat perpisahan atau yang biasa disebut depresi analitik, merupakan stres utama pada bayi usia pertengahan sampai usia prasekolah. Pada rentang usia tersebut kecemasan dimanifestasikan dalam tiga fase, yaitu fase protes, putus asa, dan pelepasan. Selama fase protes, anak-anak bereaksi secara agresif, menolak perhatian dari orang lain, dan kedukaan mereka tidak dapat ditenangkan. Selama fase putus asa, anak-anak cenderung tidak aktif, tidak tertarik, dan menarik diri dari orang lain. Sedangkan fase pelepasan, anak akan tampak menyesuaikan diri terhadap lingkungan, akan tetapi hal ini merupakan hasil dari kepasrahan dan bukan merupakan tanda-tanda kesenangan (Hockenberry \& Wilson, 2013).

Tujuan utama asuhan keperawatan anak yang dihospitalisasi adalah meminimalkan munculnya masalah pada perkembangan anak. Perawat yang melibatkan anak dalam aktivitas yang sesuai dengan tingkat perkembangan akan lebih menormalkan lingkungan anak dan membantu mengurangi gangguan perkembangan anak (Wong, 2008).

Bermain merupakan pekerjaan pada masa kanak-kanak. Ahli pekembangan anak mengakui bahwa bermain sebagai strategi koping yang penting bagi anak, hal tersebut merupakan aspek terpenting dalam kehidupan anak serta merupakan salah satu cara yang paling efektif menurunkan stres pada anak dan penting untuk menyejahterakan mental dan emosional anak (Purwandari, Mulyono, \& Sucipto, 2010).

Bermain dapat dijadikan sebagai suatu terapi karena berfokus pada kebutuhan anak untuk mengekspresikan diri mereka melalui penggunaan mainan dalam aktivitas bermain dan dapat digunakan untuk membantu anak mengerti tentang penyakitnya. Bermain terapeutik sudah diidentifikasi sebagai intervensi yang efektif untuk persiapan anak hospitalisasi, koping, pemahaman, dan prosedur untuk mengurangi nyeri, dan stres karena hospitalisasi. Prosesnya dapat dilakukan dengan cara melibatkan penggunaan film, video, atau buku-buku (Alfiyanti, Hartati \& Samiasih, 2007).

Penelitian menemukan adanya pengaruh terapi bermain terhadap tingkat kekooperatifan pada anak usia 3-5 tahun (Handayani \& Puspitasari, 2009). Begitu pun dengan penelitian Purwandari, dkk. (2010) yang menyatakan bahwa terapi bermain berdampak terhadap penurunan kecemasan perpisahan pada anak prasekolah yang mengalami hospitalisasi. Pada penelitian lain, terapi bermain menggunakan alat bantu puzzle dan musik berpengaruh pada penurunan tingkat kecemasan anak yang dihospitalisasi. Selain itu terapi membacakan dongeng pun dapat memengaruhi kecemasan anak yang dihospitalisasi (Done, 2008).

Kegiatan mendongeng dapat dilakukan dengan menggunakan alat bantu replika peralatan rumah sakit atau boneka tangan. Boneka tangan biasanya efektif untuk berkomunikasi dengan anak-anak, dan membantu mereka (Hockenberry \& Wilson, 2013). Sehingga hal ini dapat menjadi sebuah terapi, yaitu terapi mendongeng.

Mendongeng dapat meningkatkan rasa percaya (trust), menjalin hubungan, dan menyampaikan pengetahuan. Ide terapi mendongeng bukanlah konsep baru. Mendongeng sudah digunakan pada proyek komunitas, promosi kesehatan dan pencegahan penyakit, koping terhadap kesedihan, dan sebagainya (Parker \& Wampler, 2010).

Terapi ini dapat diaplikasikan pada rentang toddler dan prasekolah. Banyak orang tua meyakini bahwa pentingnya kemampuan berbahasa di masa depan (de Vris, 2008), sehingga secara tidak langsung terapi mendongeng ini dapat mengembangkan 
Nidaa'A'diilah : Efektifitas Terapi Mendongeng terhadap Kecemasan Anak Usia Toddler dan Prasekolah

kemampuan berbahasanya. Selain itu pada tingkat perkembangan, sangat sulit bagi pemberi pelayanan kesehatan untuk memberikan tindakan pada mereka (Dillon, 2007). Pada usia toddler dan prasekolah, mereka mulai tumbuh rasa untuk bersosialisasi, keingin tahuan yang tinggi, dan memiliki selfcontrol dan will power (Sue, 2010). Namun, toddler memiliki rentang perhatian yang pendek(Adriana, 2011) sehingga kemungkinan untuk menerima terapi mendongeng cukup rendah dibandingkan dengan prasekolah yang cenderung memiliki imajinasi yang tinggi.

Hasil studi pendahuluan yang dilakukan di Ruang Anak RS X melalui observasi pada 10 pasien kategori toddler-prasekolah (1-6 tahun) ditemukan 4 pasien toddler dan 2 pasien prasekolah menunjukkan reaksi cemas ketika akan dilakukan tindakan pemberian obat dan pemeriksaan tanda-tanda vital. Sedangkan 4 pasien menunjukkan sikap yang tenang.

Berdasarkan hasil wawancara dengan perawat, perlakuan perawat dalam menghadapi pasien yang mengalami kecemasan bermacammacam. Dua orang perawat mengatakan bahwa mereka biasanya menggendong pasien, dua orang perawat akan lebih melibatkan keluarga pasien, dan tiga orang mengatakan biasanya akan membuat mainan balon dari sarung tangan. Respon pasien setelah mendapatkan perlakuan perawat tersebut adalah sebagian besar pasien tetap menangis, dan sebagian kecilnya akan berhenti menangis terutama jika sudah kenal dekat dengan perawat.

Tujuan dari penelitian ini adalah untuk mengetahui efektifitas terapi mendongeng terhadap tingkat kecemasan antara anak usia toddler dan prasekolah saat tindakan keperawatan.

\section{Metode Penelitian}

Penelitian kuantitatif ini menggunakan rancangan penelitian eksperimen semu dengan menggunakan pendekatan posttest design with a comparison group (Burns \& Grove, 2007). Variabel penelitian yang digunakan adalah terapi mendongeng dan tingkat kecemasan.

Populasi penelitian adalah seluruh anak yang dirawat di Ruang Anak RS X. Teknik sampel yang digunakan adalah purposive sampling (Notoatmodjo, 2010) didapatkan 15 responden untuk tiap kategori dengan kriteria inklusi: anak dirawat pada hari ke 1-3 di rumah sakit, tidak mengalami gangguan mental, berada pada rentang skor kecemasan 7-9, dan belum pernah mempunyai pengalaman dirawat di rumah sakit (baru pertama kali dirawat di rumah sakit).

Instrumen yang digunakan di buat berdasarkan ciri-ciri kecemasan berdasarkan teori kecemasan hospitalisasi pada anak dari Wong (2008) dan The Assesment of Anxiety States by Rating dari Hamilton (de Vries, 2008).

Peneliti mengambil data primer melalui mengobservasi secara langsung kepada responden sebanyak dua kali kunjungan. Kunjungan pertama merupakan observasi awal untuk menentukan kesesuaian klien dengan kriteria inklusi. Jika klien layak, maka langkah selanjutnya adalah mengeksplorasi minat responden dari orang tua/ wali sebagai bahan materi untuk dongeng.

Kunjungan kedua adalah pemberian terapi mendongeng selama tiga menit menggunakan alat bantu berupa boneka tangan berbentuk binatang. Setelah itu, perawat memberikan tindakan (dalam hal ini pemberian obat melalui selang infus) kepada responden dan peneliti mengobservasi skor kecemasan responden dan mencatatnya pada lembar observasi.

Data dianalisis dengan menggunakan nilai-niai numeriknya terutama pada variable kecemasan, dimana data yang muncul adalah nilai tengah (rata-rata skor kecemasan), dan niai penyimpangan (standar deviasi, rentang, 95\% confidence interval).

Analisis data untuk melihat perbedaan efektifitas terapi mendongeng terhadap kecemasan anak menggunakan analisis parametrik dikarenakan data yang digunakan adalah data dengan skala numeriknya, untuk melihat perbedaan kecemasan diantara kedua kelompok sampel maka dilakukan dengan uji t tidak berpasangan.

\section{Hasil Penelitian}

Karakteristik responden dalam penelitian ini meliputi jenis kelamin dan hari dirawat. Berdasarkan Tabel 1, karakteristik responden toddler dan prasekolah di Ruang Anak RS X memiliki frekuensi jenis kelamin yang sama, 
Nidaa' A'diilah : Efektifitas Terapi Mendongeng terhadap Kecemasan Anak Usia Toddler dan Prasekolah

terdiri dari laki-laki sebanyak $46,7 \%$ dan perempuan $53,3 \%$.

Hal ini menyatakan bahwa jenis kelamin tidak berpengaruh besar dalam hasil penelitian ini. Pada karakteristik hari dirawat, kelompok toddler lebih banyak dilakukan pengambilan data pada hari ke-2 yaitu sebesar 53,3\%, sedangkan pada kelompok prasekolah adalah anak yang dirawat pada hari ke-3 sebesar 66,7\%. Hari ke- dirawat berpengaruh pada skor kecemasan anak. Semakin lama dia dirawat, maka skor kecemasan akan semakin rendah.

\section{Kecemasan Anak}

Skor kecemasan dalam rentang 0-18. Skor 0 berarti anak tidak mengalami kecemasan, sedangkan skor 18 memiliki arti bahwa anak megalami kecemasan yang sangat.

Pada Tabel 2, kedua kelompok memiliki nilai mean dibawah 7 (skor kecemasan awal responden 7-9). Hal ini menunjukkan bahwa telah terjadi penurunan skor kecemasan dari keadaan sebelum diberikan terapi mendongeng. Toddler memiliki nilai tendensi sentral lebih tinggi dibandingkan prasekolah $(\mathrm{M}=4,4 ; \mathrm{SD}=1,72)$. Hal ini menyatakan bahwa prasekolah memiliki skor kecemasan yang lebih rendah dibandingkan prasekolah setelah pemberian terapi mendongeng.

\section{Pengaruh Terapi Mendongeng terhadap Kecemasan Anak}

Pengaruh terapi mendongeng terhadap kecemasan anak dapat dilihat pada tabel 3 . Tabel 3 diketahui nilai $p$ adalah $<0,05$ dengan mean difference sebesar 2,53. Karena $p$ value $<0,05$ maka diambil kesimpulan hipotesis diterima yang artinya ada beda skor kecemasan pada anak usia toddler dan prasekolah setelah

Tabel 1 Karakterisitik Responden

\begin{tabular}{lcccc}
\hline \multirow{2}{*}{ Karakteristik } & \multicolumn{2}{c}{ Toddler $(\mathbf{n}=\mathbf{1 5})$} & \multicolumn{2}{c}{ Prasekolah $(\mathbf{n}=\mathbf{1 5})$} \\
\cline { 2 - 5 } & Frekuensi & $\mathbf{\%}$ & Frekuensi & \% \\
\hline Jenis Kelamin & & & & 46,7 \\
Laki-laki & 7 & 46,7 & 7 & 53,3 \\
Perempuan & 8 & 53,3 & 8 & \\
Hari rawat Ke- & & & & 13,3 \\
1 & 0 & 0,0 & 2 & 20,0 \\
2 & 8 & 53,3 & 3 & 66,7 \\
3
\end{tabular}

Tabel 2 Deskripsi Skor Kecemasan Toddler Dan Prasekolah

\begin{tabular}{|c|c|c|c|}
\hline & & Toddler & Prasekolah \\
\hline Mean & & 4,40 & 1,87 \\
\hline Std. Deviation & & 1,72 & 1,30 \\
\hline Minimum & & 1,00 & 0,00 \\
\hline Maximum & & 7,00 & 5,00 \\
\hline Range & & 6,00 & 5,00 \\
\hline \multirow[t]{2}{*}{ 95\% Confidence Interval for Mean } & Lower Bound & 3,44 & 1,15 \\
\hline & Upper Bound & 5,35 & 2,59 \\
\hline
\end{tabular}

Tabel 3 Hasil Uji t-Tidak Berpasangan

\begin{tabular}{lcccc}
\hline & N & Mean \pm SD & MD (95\% $\boldsymbol{C I})$ & $\boldsymbol{P}$ \\
\hline Toddler & 15 & $4,40 \pm 1.72$ & & 0,000 \\
Prasekolah & 15 & $1,87 \pm$ & $2,53(3,67-1,39)$ & \\
& & 1.30 & & \\
\hline
\end{tabular}


Nidaa'A'diilah : Efektifitas Terapi Mendongeng terhadap Kecemasan Anak Usia Toddler dan Prasekolah

pemberian terapi mendongeng.

\section{Pembahasan}

Proses hospitalisasi anak akan sering menimbulkan kecemasan karena adanya stresor berupa perpisahan dengan keluarga, kehilangan kontrol, dan ketakutan akan injuri terhadap anggota tubuh (Potter, 2013). Selama dirawat di rumah sakit ini, anak mengalami perpisahan dengan keluarga, berada di lingkungan yang asing, dan harus menjalani beberapa prosedur keperawatan/medis. Banyak reaksi yang muncul akibat keadaan tersebut. Namun, secara garis besar reaksi yang muncul dipengaruhi oleh usia perkembangan; pengalaman sebelumnya dengan penyakit, perpisahan, atau hospitalisasi; keterampilan koping yang dimiliki; keparahan diagnosis; dan sistem pendukung yang ada (Hockenberry \& Wilson, 2013).

Kecemasan yang dialami anak selama dilakukan tindakan keperawatan dipengaruhi oleh kecemasan hospitalisasi, yang terdiri dari tiga fase. Pertama fase protes, ditunjukkan dengan reaksi anak yaitu menangis, berteriak, mencari dan memegang erat orang tua, menolak bertemu dan menyerang orang yang tidak dikenal baik secara verbal maupun fisik. Kedua adalah fase putus asa yang ditandai dengan anak tidak aktif, menarik diri dari orang lain, sedih, tidak tertarik terhadap lingkungan, tidak komunikatif, dan menolak makan atau minum. Pada fase ketiga, yaitu fase penerimaan, anak mulai menunjukkan ketertarikan pada lingkungan dan berinteraksi dangkal dengan orang lain atau perawat (Hockenberry \& Wilson, 2013).

Pada hari pertama anak dirawat di rumah sakit, anak berada pada fase pertama yaitu fase protes. Anak masih belum merasa nyaman berada di rumah sakit. Mereka menolak kenyataan bahwa mereka harus berada di rumah sakit dengan menerima berbagai macam terapi. Belum lagi, mereka harus beradaptasi dengan lingkungan, rutinitas, dan orang-orang yang baru. Bukan lagi teman yang ada untuk mengajak bermain, akan tetapi perawat dan tim medis lain yang sering datang mengunjungi mereka dan memberikan berbagai macam prosedur yang membuat stres. Hal ini mengindikasikan bahwa anak belum melewati fase adaptasi untuk mencapai tahap penerimaan, karena tahap penerimaan ini biasanya terjadi setelah anak dirawat di rumah sakit selama beberapa hari atau dalam jangka waktu lebih dari tiga hari dan tiap anak memiliki waktu adaptasi yang berbeda-beda (Hockenberry \& Wilson, 2013).

Fase kecemasan ini dapat diminimalisasi dengan cara memberikan permainan terapeutik kepada anak. Permainan terapeutik ini merupakan koping bagi mereka untuk menghadapi hal-hal yang baru dan membuat stres. Perawat dapat membantu anak untuk beradaptasi dengan kecemasan mereka akan tindakan keperawatan ataupun medis lainnya dan meluruskan kesalahpahaman yang dimiliki anak-anak tentang hospitalisasi. Dalam aktivitas permainan terapeutik ini, anak diajarkan untuk mengontrol kesehatan emosional dan dipahamkan tentang penyakitnya.

Permainan terapeutik memiliki beberapa tujuan, yaitu aktivitas pembelajaran, aktivitas pengalihan, dan aktivitas ekspresif. Permainan terapeutik sebagai aktivitas pengalihan atau diversional membantu anak dalam mengalihkan perhatian pada aktivitas yang disukainya (Hockenberry \& Wilson, 2013). Mendongeng merupakan salah satu aktivitas yang dapat digunakan dan sesuai dengan perkembangan umur mereka (Andriana, 2011).

Mendongeng merupakan suatu kegiatan menyampaikan dongeng secara lisan pada pendengar dengan menggunakan gaya tertentu yang menarik perhatian (Bimo, 2011). Selain merupakan aktivitas pengalihan dari kecemasan, pada mendongeng pun terjadi proses reframing yang merupakan teknik lain untuk menurunkan kecemasan. Teknik reframing mengajarkan klien untuk mengontrol pikiran negatif mereka dengan cara mengubah pandangan mereka ke arah yang lebih positif (Sue, 2010). Cara mengubah pandangan yang dilakukan pada proses mendongeng dilakukan melalui alur cerita yang telah di atur sedemikian rupa. Alur cerita akan menjelaskan bahwa persepsi yang selama ini anak miliki mengenai hospitalisasi tidak sepenuhnya benar. Dalam prosesnya, perawat seakan-akan menasehati tanpa anak merasa dinasehati atau bahkan dimarahi (Nur'aini, 2010). Akhirnya, anak merasa nyaman mendengar dan ikut aktif 
Nidaa' A'diilah : Efektifitas Terapi Mendongeng terhadap Kecemasan Anak Usia Toddler dan Prasekolah

mengambil bagian atau peran dalam alur cerita tersebut. Terlebih lagi, terapi mendongeng ini melibatkan boneka peraga sebagai alat bantu visual sehingga secara tidak sadar anak-anak tertarik dan larut dalam alur cerita.

Hasil penelitian mendapatkan hasil $p$-value $<0,001$ dengan nilai mean dibawah 7 (toddler 4,40; prasekolah 1,87) dari skor awal 7-9 yang berarti bahwa terapi mendongeng berpengaruh dalam menurunkan skor kecemasan terhadap tindakan keperawatan, baik pada anak usia toddler maupun prasekolah. Kedua kelompok ini dapat menerima terapi dongeng sebagai aktivitas yang mampu mengalihkan perasaan cemas mereka terhadap tindakan keperawatan yang bersifat invasive misalnya memasukan obat melalui selang infus.

Anak-anak sangat mudah terkena krisis akibat kesakitan dan rawat inap dikarenakan mereka memiliki mekanisme adaptif yang terbatas untuk memecahkan faktor stres. Mendongeng dapat mengurangi semua dimensi kecemasan fisiologis dan sosial. Oleh karena itu, penggunaan kegiatan mendongeng sebagai intervensi non-farmakologis, mudah, tidak mahal, disarankan untuk digunakan kepada anak-anak. (Zarei, Motlagh, Seyedfatem, Khoshbakh, Haghan, \& Zarei, 2013).

Penelitian lain didapatkan penurunan skor kecemasan pada pasien anak-anak yang menunjukkan bahwa mendongeng merupakan kegiatan untuk menurunkan tingkat kecemasan dari anak-anak yang sedang dirawat (Kanchan, Chandra, \& Aarti, 2015).

Sejalan dengan yang dipaparkan oleh Andriana (2011) bahwa kegiatan bermain yang dapat diaplikasikan kepada anak usia toddler dan prasekolah adalah kegiatan bermain yang bersifat asosiatif (interaktif dan kooperatif) ataupun parallel, salah satunya adalah mendongeng.

Adapun nilai mean kelompok prasekolah menunjukkan lebih rendah dibandingkan dengan toddler. Hal tersebut berarti terapi mendongeng lebih efektif diberikan pada kelompok prasekolah. Sebagaimana studi Piaget bahwa anak usia prasekolah cenderung memiliki pemikiran perseptual yang terbatas, dimana anak-anak menilai orang, benda, dan kejadian dari penampilan luar atau apa yang tampaknya terjadi (Potter, 2013).

Anak usia pra-sekolah menganggap bahwa semua prosedur baik yang menimbulkan nyeri atau tidak sebagai sesuatu yang akan melukai tubuhnya. Selain itu pengetahuan anak prasekolah tentang dunia tetap terhubung secara erat pada pengalaman konkret, bahkan kehidupan mereka yang kaya fantasi dan magis didasarkan pada persepsi tentang realitas (Potter, 2013). Fantasi mereka mampu melakukan reframing dengan cepat terhadap pesan-pesan yang tersurat dalam dongeng. Mereka tidak lagi menganggap bahwa perawat yang akan memasukan obat ke dalam tubuh mereka itu adalah sosok yang menakutkan, akan tetapi mereka mencoba menerima bahwa perawat adalah sosok yang akan menyembuhkan dan membuat mereka cepat keluar dari rumah sakit. Sehingga terapi mendongeng yang bersifat distraksi atau aktivitas yang bersifat mengalihkan perhatian dari hal yang ingin dihindari (Sue, 2002) dapat secara efektif diaplikasikan kepada anak usia prasekolah. Terapi bermain dalam hal ini dalam bentuk terapi mendongeng dapat berpengaruh terhadap tingkat kecemasan pada usia anak pra sekolah (Alfiyanti, Hartati, \& Samiasih, 2007).

Anak usia toddler, tingkat kognitif mereka masih di bawah prasekolah. Walaupun samasama dapat menurunkan skor kecemasan ( mean $=4,40)$, namun prilaku anak pada usia ini semata-mata hanya untuk menghindari hal yang tidak menyenangkan dan mencari hal yang menyenangkan (Potter, 2013). Mereka menganggap bahwa dongeng dan boneka peraga adalah hal yang menarik. Mereka antusias untuk terlibat aktif dalam alur cerita yang menggunakan nama mereka sebagai nama salah satu tokoh cerita. Namun, hal ini mereka lakukan hanyalah sebagai bentuk pengalihan dari rasa cemas mereka.

Sedikit hal positif dari proses reframing yang dapat mereka ambil jika dibandingkan dengan kelompok prasekolah. Karena, pada saat toddler dihadapkan kembali dengan tindakan keperawatan yang harus mereka terima, banyak dari mereka yang kembali pada kecemasannya dan hanya sebagian yang fokus pada dongeng. Hal tersebut dipengaruh oleh faktor kognitif usia 18 bulan yang baru menggunakan hampir 100 kata dan 24 bulan yang baru memiliki kosakata sampai 300 kata dan secara umum mampu berbicara dalam kalimat yang pendek (Andriana, 2011). 
Nidaa'A'diilah : Efektifitas Terapi Mendongeng terhadap Kecemasan Anak Usia Toddler dan Prasekolah

Sehingga proses reframing tidak dapat secara optimal dimengerti oleh toddler.

\section{Simpulan}

Terapi mendongeng efektif terhadap penurunan skor kecemasan baik pada anak usia toddler maupun anak usia pra-sekolah, namun berdasar analisis uji beda didapatkan perbedaan skor kecemasan pda anak usia toddler dan prasekolah setelah pemberian terapi mendongeng selama tindakan keperawatan di RS X. Jadi meskipun terapi ini dapat memberikan efek menurunkan kecemasan, tetapi terapi mendongeng akan lebih efektif diberikan kepada kelompok usia praskolah dibandingkan dengan usia toddler, hal ini berhubungan dengan proses tumbuh kembang pada anak usia prasekolah yang sudah mampu melakukan reframing pesanpesan lebih baik dibandingkan dengan usia toddler. Anak pada usia prasekolah akan lebih cepat untuk memberikan makna bagi dongen yang diberikan oleh perawat.

Berdasarkan hasil diatas maka terapi mendongeng dapat dijadikan sebagai alternatif tindakan keperawatan untuk mengatasi masalah keperawatan kecemasan terutama bagi anak usia prasekolah, begitu pula dengan anak usia toddler.

\section{Daftar Pustaka}

Alfiyanti, D., Hartiti, T., \& Samiasih, A. (2007). Pengaruh terapi bermain terhadap tingkat kecemasan anak usia prasekolah selama tindakan keperawatan di Ruang Lukman Rumah Sakit Roemani Semarang. Jurnal Keperawatan, 35-44.

Andriana, D. (2011). Tumbuh kembang \& terapi bermain pada anak. Jakarta: Salemba Medika.

Burns, N., \& Grove, S.K. (2007). Understanding nursing research "Building an evidence based practicce" ( $4^{\text {th }}$ Ed.). Missouri: Saunders Elseviers.

de Vries, P. A. (2008). Parental perception of music in storytelling session in a Public
Library. Early Childhood Educ J., 473-478.

Dillon, P.M. (2007). Nursing health assessment: A critical thinking, case studies approach. Philadelphia: F. A. Davis Company.

Done, A. (2001). The therapeutic use of storytelling. Paediatric Nursing, 17-20.

Handayani, R., \& Puspitasari.(2009). Pengaruh terapi bermain terhadap tingkat kooperatif selama menjalani perawatan pada anak usia prasekolah (3-5 tahun) di Rumah Sakit Panti Rapih Yogyakarta. Jurnal Kesehatan Surya Medika.

Hockenberry, M.J., \& Wilson, D. (2013). Wong's essentials of pediatric nursing $\left(9^{\text {th }}\right.$ Ed.). St. Louis: Mosby).

Kanchan, L., Chandra, S. M., \& Aarti, S. (2015, Oktober). A Randomized Clinical Trial to Evaluate the Effectiveness of Storytelling by Researcher on the Hospitalization Anxiety of Children Admitted in Pediatric Ward of Selected Hospitals of District Patiala, Punjab. International Journal of Science and Research (IJSR), 4(10), 706-709.

Notoatmodjo. (2010). Metodologi Penelitian Kesehatan. Jakarta: Rineka Cipta

Parker, T.S., \& Wampler, K.S. (2010). Changing emotion: The use of therapeutic storytelling. Journal of Marital and Family Therapy, 32, 155-166.

Potter, P.A. (2005). Buku ajar fundamental keperawatan: Konsep, proses, dan praktik. Jakarta: Penerbit Buku Kedokteran EGC.

Purwandari, H., Mulyono, W.A., \& Sucipto, A. (2010). Terapi bermain untuk menurunkan kecemasan perpisahan pada anak prasekolah yang mengalami hospitalisasi. Jurnal Keperawatan Profesional Indonesia, 52-59.

Sue, D.C. (2010). Fundamentals of nursing: Standards \& practice, ( ${ }^{\text {nd }}$ Ed.). New York: Delmar.

Wong, D.L. (2008). Wong, buku ajar keperawatan pediatrik (Vol 2). Jakarta: EGC. 